\title{
Physicochemical Properties of Two Generations of MTA-Based Root Canal Sealers
}

\author{
Sawsan Abu Zeid ${ }^{1,2, *}$, Hadeel Yaseen Edrees ${ }^{1}$ (D) Abeer Abdulaziz Mokeem Saleh ${ }^{1}$ and Osama S. Alothmani ${ }^{1}$ (D) \\ 1 Department of Endodontics, Faculty of Dentistry, King Abdulaziz University, Jeddah 21589, Saudi Arabia; \\ hedrees@kau.edu.sa (H.Y.E.); aasaleh@kau.edu.sa (A.A.M.S.); osalothmani@kau.edu.sa (O.S.A.) \\ 2 Department of Endodontics, Faculty of Dentistry, Cairo University, Cairo 12613, Egypt \\ * Correspondence: sawsanabuzeid55@hotmail.com
}

Citation: Abu Zeid, S.; Edrees, H.Y.; Mokeem Saleh, A.A.; Alothmani, O.S. Physicochemical Properties of Two Generations of MTA-Based Root Canal Sealers. Materials 2021, 14, 5911 https://doi.org/10.3390/ma14205911

Academic Editor: Alessandro Vichi

Received: 31 August 2021

Accepted: 29 September 2021

Published: 9 October 2021

Publisher's Note: MDPI stays neutral with regard to jurisdictional claims in published maps and institutional affiliations.

Copyright: (c) 2021 by the authors. Licensee MDPI, Basel, Switzerland. This article is an open access article distributed under the terms and conditions of the Creative Commons Attribution (CC BY) license (https:/ / creativecommons.org/licenses/by/ $4.0 /)$.

\begin{abstract}
This study evaluated the physicochemical properties and the effect of solubility on the surface morphology and composition of the root canal sealers MTA-Bioseal, MTA-Fillapex, and Adseal. Discs $(n=10)$ of freshly mixed sealer were prepared and then analyzed by Fourier transform infrared (FTIR) spectroscopy and scanning electron microscopy/energy-dispersive X-ray spectroscopy (SEM/EDX). The discs were immersed for 1, 7, 14, and 28 days in deionized water. The solubility $\% ; \mathrm{pH}$ change of the solution; and released calcium, phosphate, and silicon were measured for each period. The flowability and film thickness were also evaluated. Changes in the surface morphology and composition after 28 days of immersion were evaluated by SEM/EDX. The data were statistically analyzed by one-way ANOVA at $p<0.05$. The FTIR and EDX results revealed similar compositions of MTA-Bioseal and MTA-Fillapex, but with different concentrations. The two MTA-based sealers had higher solution alkalinity $(\mathrm{pH}>10)$ than Adseal $(\mathrm{pH} \approx 8.5)$. MTA-Fillapex exhibited the highest solubility $\%$ and the largest calcium and silicon ion release. MTA-Bioseal had the highest phosphate ion release. After 28 days, the sealer surfaces showed large micropores, with larger pores in MTAFillapex. Adseal had an intermediate flowability but exhibited the greatest film thickness. Finally, the highest solubility and largest amount of silicon release was exhibited by MTA-Fillapex, which might predispose it to the development of large micropores, compromising the apical seal of obturation.
\end{abstract}

Keywords: MTA-based root canal sealer; physical and chemical properties; $\mathrm{pH}$; solubility; releasing element

\section{Introduction}

Fostering a fluid-tight apical seal throughout the root filling after instrumentation is crucial for a favorable long-term outcome of root canal treatment. Because gutta-percha lacks adhesiveness, a root canal sealer must be used to fill the minute spaces between the gutta-percha and the canal wall to provide a three-dimensional seal of the root canal system [1].

A wide variety of root canal sealers is commercially available, and these possess different compositions and physicochemical properties. A sealer's performance depends on its composition and physical and chemical properties. Owing to the favorable cohesive strength, biological behavior, and osteogenic potential of mineral trioxide aggregate (MTA) [2], several MTA-based root canal sealers have been formulated to utilize these advantages. MTA-Fillapex was the first generation of MTA-based root canal sealer and was launched by Angelus (Angelus, Londrina, Brazil) in 2010 as a paste-paste formulation [3]. According to the suggested ideal requirements for an endodontic sealer proposed by Grossman [4], to achieve three-dimensional obturation, the sealer should be insoluble in tissue fluid, inhibit bacterial growth, and properly flow along the dentinal tubules when it is first applied. In previous studies, MTA-Fillapex showed a high solubility that exceeded the acceptable limit $[5,6]$. Another study showed that MTA-Fillapex was cytotoxic for 4 weeks after its application, which was attributed to its high dissolution rate [7]. 
A new MTA-based sealer, MTA-Bioseal, has been recently introduced by ITENA Clinical (Paris, France). The manufacturer claims it exhibits limited expansion during setting, low solubility when it contacts tissue fluid, and optimal flowability [8]. However, no available studies have reported its physical and chemical properties.

The current study evaluated the physicochemical properties (solubility \%; $\mathrm{pH}$ changes; released calcium, phosphate, and silicon ions; flowability; and film thickness) and the effect of solubility on surface morphology and composition of two generations of MTA-based root canal sealers (MTA-Fillapex and MTA-Bioseal) and compared them with an epoxy resin-based sealer (Adseal, META Biomed Co., Chungbuk, Korea), which was considered as a control. The null hypothesis was that there would be no significant difference among the tested sealers for any of the parameters assessed.

\section{Materials and Methods}

The study design and protocol were approved by the Ethics Committee of the Faculty of Dentistry, King Abdulaziz University (\#216-01-21).

\subsection{Sample Preparation}

According to ISO 6876 and ANSI/ADA Specification No. 57 for root canal filling $[9,10]$, a fresh mix of each sealer was prepared in accordance with the manufacturer's instructions and inserted into a polyethylene mold (10 mm diameter, $3 \mathrm{~mm}$ high). Discs $(n=10 /$ sealer $)$ were wrapped with moistened gauze and incubated at $37^{\circ} \mathrm{C}$ and $100 \%$ humidity until material hardening.

\subsection{Fourier Transform Infrared (FTIR) Analysis}

One disc of each sealer was analyzed by FTIR spectroscopy (Vertex 80v, Bruker, Karlsruhe, Germany) to determine the composition. The spectra were obtained at $4000-400 \mathrm{~cm}^{-1}$ and $4 \mathrm{~nm}$ resolution.

\subsection{Solubility}

After complete hardening, each disc was weighed (W0) using an electric balance (\#ZSA210, Scientech, Boulder, CO, USA), placed in a vial containing $10 \mathrm{~mL}$ of deionized water, and incubated at $37^{\circ} \mathrm{C}$ and $100 \%$ humidity. After each immersion period $(1,7$, 14 , and 28 days), the discs were removed and dried on blotting paper overnight, then reweighed (Wt1, Wt7, Wt14, and $\mathrm{Wt} 28)$. The solubility percentage (\%) was calculated by the following Equation (1) [11]:

$$
\text { Solubility } \%=\frac{W 0-W t 1}{W 0} \times 100
$$

\section{4. $p H$ Changes}

After each immersion period, the solution was evaluated for $\mathrm{pH}$ changes at $25^{\circ} \mathrm{C}$ using a pH meter (Jenway $3510 \mathrm{pH}$ meter, Bibby Scientific Ltd., Stone, UK) initially calibrated with standard $\mathrm{pH} 4.0$ and 7.0 solutions [5].

\subsection{Released Elements}

After each immersion period, the deionized water was analyzed for the amount of released calcium $\left(\mathrm{Ca}^{2+}\right)$, phosphorus $\left(\mathrm{P}^{3-}\right)$, and silicon $\left(\mathrm{Si}^{4+}\right)$ ions, which were respectively analyzed using an EDTA titration method [12], a colorimetric method with a spectrophotometer (Jenway $6705 \mathrm{UV} /$ Vis spectrophotometer, Stone, UK) [13,14], and inductively coupled plasma optical emission spectroscopy (Agilent 5100, Santa Clara, CA, USA).

\subsection{Scanning Electron Microscopy (SEM) and Energy-Dispersive X-ray (EDX) Analysis}

The set discs were analyzed by SEM/EDX (Octane pro, 7.2/15252, EDAX, Ametek Material Analysis Division, Mahwah, NJ, USA) to determine the surface morphology and composition of each sealer before immersion in deionized water. At the end of the final 
immersion period (i.e., after 28 days), the discs were reexamined to determine the surface and composition changes consequent to solubility. The microporosities in each image were measured using ImageJ software, a Java-based image processing program, (version 1.44, 64-bit Java 1.8.0_112, National Institutes of Health, Bethesda, MD, USA).

\subsection{Flowability and Film Thickness}

The flowability test was conducted based on ISO 6876/2001 for dental root canal sealing material [10]. One drop of $0.05 \pm 0.005$ volumes of each mixed sealer $(n=5)$ was applied onto a glass slab $\left(35 \times 35 \times 6 \mathrm{~mm}^{3}\right)$ [15]. After $3 \mathrm{~min}$, it was covered by another glass slab weighing $20 \mathrm{mg}$, and an additional weight of $100 \mathrm{~g}$ was placed on the top of the spreading sealer. The two glass slabs containing the sealer and the $100 \mathrm{~g}$ weight were incubated for $10 \mathrm{~min}$ at $37^{\circ} \mathrm{C}$ and $100 \%$ humidity. After removing the weight and the upper glass slab, the dimensions of the circular sample were measured using a digital caliper (Cole-Parmer Canada Inc., Montreal, QC, Canada). In cases where the obtained circle was not uniform or if the dimension exceeded $1 \mathrm{~mm}$, the test was repeated.

After finishing the flowability test, the thickness of the double slab containing the set sealer (Ts) was measured by a digital caliper. The thickness of an empty double slab (T0) was also measured. The sealer film thickness was calculated as Ts-T0.

\subsection{Statistical Analysis}

The recorded data (solubility \%; $\mathrm{pH}$; released $\mathrm{Ca}^{2+}, \mathrm{PO}_{4}{ }^{3-}$, and $\mathrm{Si}^{4+}$; and $\mathrm{EDX}$ ) were statistically analyzed by one-way ANOVA and the post hoc Tukey HSD test using SPSS software (version 20.0; SPSS, Inc., Chicago, IL, USA). Comparisons of the sealers were analyzed at a $5 \%$ significance level.

\section{Results}

\subsection{FTIR Analysis}

The FTIR spectra of MTA-Bioseal and MTA-Fillapex showed a similar composition (Figure 1 and Table 1). Spectra of both sealers showed sharp bands for calcium hydroxide $\left(\mathrm{Ca}(\mathrm{OH})_{2}\right)$; a broad band of the hydroxyl ion $(\mathrm{OH})$ of absorbed water; bands of methyl $(\mathrm{C}-\mathrm{H})$ (Figure $1 \mathrm{~A})$ and amide $\mathrm{I}(\mathrm{C}=\mathrm{O})$ from salicylate resin; and bands for carbonate groups $\left(\mathrm{CO}_{3}{ }^{2-}\right)$, sulfate $\left(\mathrm{SO}_{4}{ }^{2-}\right)$, and silicate groups $(\mathrm{Si}-\mathrm{O})$ from tri-calcium silicate $\left(\mathrm{C}_{3} \mathrm{~S}\right)$, dicalcium silicate $\left(\mathrm{C}_{2} \mathrm{~S}\right)$, and / or calcium silicate hydrate (CSH) (Figure 1B). In addition, the spectra of MTA-Bioseal showed phosphate bands $\left(\mathrm{v}_{3}\right.$ and $\left.\mathrm{v}_{4} \mathrm{PO}_{4}{ }^{3-}\right)$. The spectra of Adseal showed amide $\mathrm{I}(\mathrm{C}=\mathrm{O})$, carbonate $\left(\mathrm{CO}_{3}{ }^{2-}\right)$, silicate $(\mathrm{Si}-\mathrm{O})$, and phosphate $\left(\mathrm{v}_{3}\right.$ and $\left.\mathrm{v}_{4} \mathrm{PO}^{3-}\right)$ bands (Figure 1 and Table 1).

Table 1. Fourier transform infrared spectroscopy (FTIR) information of analyzed root canal sealers.

\begin{tabular}{|c|c|c|c|}
\hline $\begin{array}{l}\text { MTA-Bioseal } \\
\quad\left(\mathrm{cm}^{-1}\right)\end{array}$ & $\begin{array}{l}\text { MTA-Fillapex } \\
\quad\left(\mathrm{cm}^{-1}\right)\end{array}$ & $\begin{array}{l}\text { Adseal } \\
\left(\mathrm{cm}^{-1}\right)\end{array}$ & Assignment (Vibration Mode) (Reference) \\
\hline 3642 & 3641 & & $\mathrm{Ca}(\mathrm{OH})_{2}[16-19]$ \\
\hline 3292 & 3298 & & $\mathrm{OH}[19]$ \\
\hline $\begin{array}{c}2954,2923,2854,1321, \\
1315\end{array}$ & $2972,2935,2873,1318$ & & $\mathrm{CH}[18]$ \\
\hline 1666 & 1671 & 1631 & $\mathrm{C}=\mathrm{O}$ of amide $\mathrm{I}[20]$ \\
\hline 1465,1446 & 1464 & 1458 & $\mathrm{CO}_{3}{ }^{2-}[16,17,19,20]$ \\
\hline 1321 & 1320 & 1303 & $\mathrm{CO}[20,21]$ \\
\hline 1215 & 1248,1215 & 1246 & $\mathrm{C}-\mathrm{O}$ of aromatic [21] \\
\hline \multirow[t]{2}{*}{1155} & 1157 & 1165 & $\mathrm{SO}_{4}^{2-}[17,19]$ \\
\hline & 1112 & & $\mathrm{SiO}_{4}[18]$ \\
\hline 1086 & & 1031 & $\mathrm{~V}_{3} \mathrm{PO}[16,20,22]$ \\
\hline 950 & 947 & & $\mathrm{Si}-\mathrm{O}$ of calcium silicate hydrate (CSH) [19] \\
\hline & 860,815 & & $\begin{array}{l}\text { Si-O of lowly polymerized silicate }(\mathrm{CxS})[18,23] \\
\qquad(445+815+950=\mathrm{C}-\mathrm{S}-\mathrm{H})\end{array}$ \\
\hline $795,75,710$ & 760 & 710,673 & symmetric stretching of $\mathrm{v}_{4} \mathrm{SiO}_{4}$ of $\mathrm{CSH}$ [19] \\
\hline
\end{tabular}


Table 1. Cont.

\begin{tabular}{|c|c|c|c|}
\hline $\begin{array}{l}\text { MTA-Bioseal } \\
\left(\mathrm{cm}^{-1}\right)\end{array}$ & $\begin{array}{l}\text { MTA-Fillapex } \\
\left(\mathrm{cm}^{-1)}\right)\end{array}$ & $\begin{array}{l}\text { Adseal } \\
\left(\mathrm{cm}^{-1}\right)\end{array}$ & Assignment (Vibration Mode) (Reference) \\
\hline \multirow[t]{2}{*}{701} & 701,690 & & $\mathrm{CO}_{3}$ of aragonite [24] \\
\hline & & 618,568 & $\mathrm{v}_{4} \mathrm{PO}[22]$ \\
\hline 592 & & & $\mathrm{SiO}_{4}{ }^{2-}$ bending of $\mathrm{C}_{3} \mathrm{~S}[16-18]$ \\
\hline 465 & 464 & 500 & $\mathrm{SiO}_{4}{ }^{2-}$ bending of $\mathrm{C}_{2} \mathrm{~S}[18]$ \\
\hline 440 & 428 & 412 & $\mathrm{O}-\mathrm{Si}-\mathrm{O}$ of $\mathrm{CSH}[17,18]$ \\
\hline
\end{tabular}
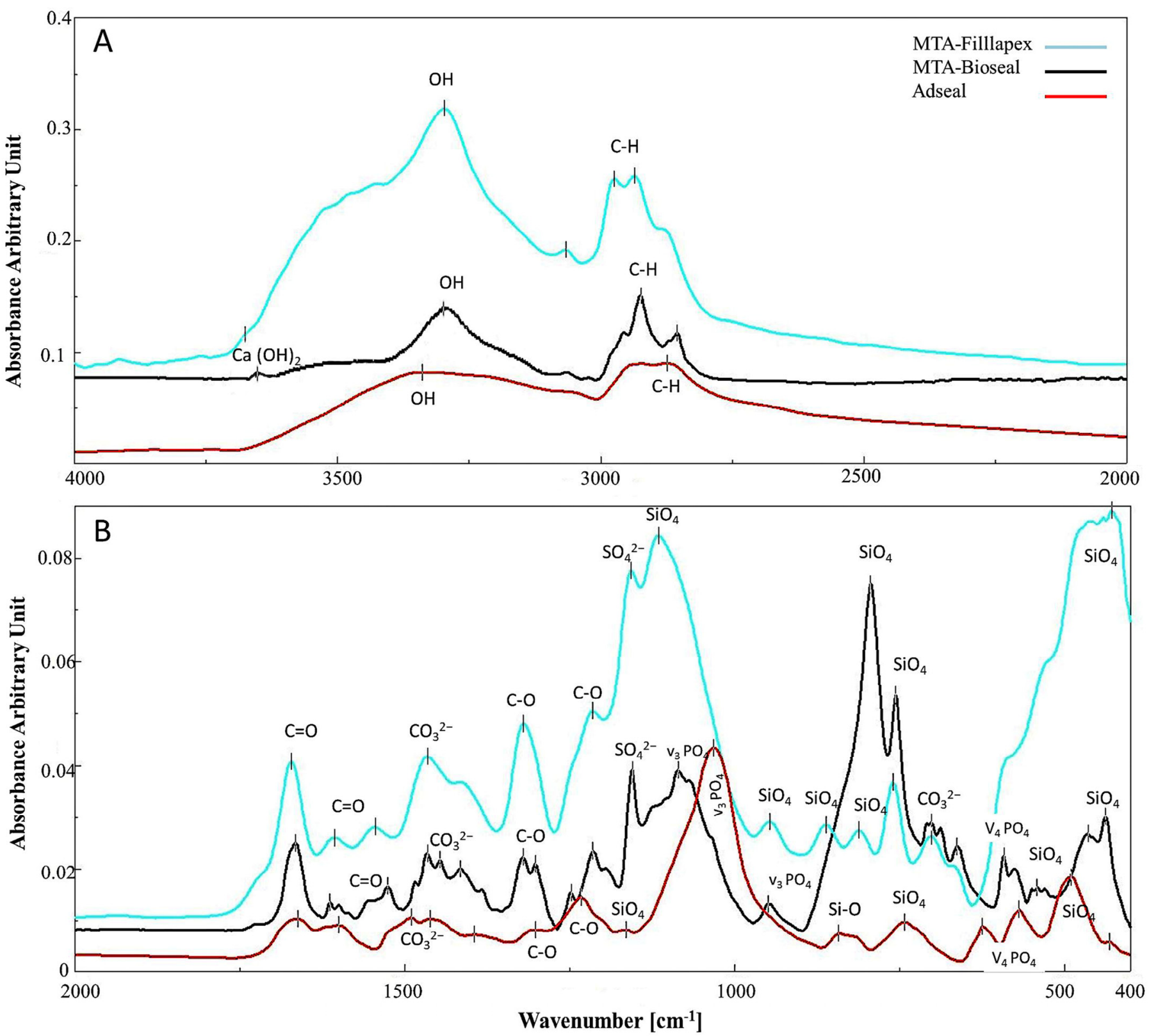

Figure 1. FTIR spectra of hydrated root canal sealers showing the composition of each sealer. At region $4000-2000 \mathrm{~cm}^{-1}$ (A), the spectra detected bands of calcium hydroxide $\left(\mathrm{Ca}(\mathrm{OH})_{2}\right)$, hydroxyl ion of absorbent water $(\mathrm{OH})$, methyl $(\mathrm{C}-\mathrm{H})$. At region $2000-400 \mathrm{~cm}^{-1}(\mathrm{~B})$, the spectra detected amide $\mathrm{I}(\mathrm{C}=\mathrm{O})$ of salicylate resin, carbonate $\left(\mathrm{CO}_{3}{ }^{2-}\right)$, sulfate $\left(\mathrm{SO}_{4}{ }^{2-}\right)$, phosphate $\left(\mathrm{PO}_{4}\right)$, and silicate group $\left(\mathrm{SiO}_{4}\right)$ of calcium silicate. 


\subsection{Solubility $\%$}

Both of the MTA-based sealers demonstrated an increased mean solubility \% over time, with no significant difference $(p>0.05)$ between them. Adseal showed a significantly lower solubility \% compared with the MTA-based sealers $(p<0.001)$ (Figure 2A).
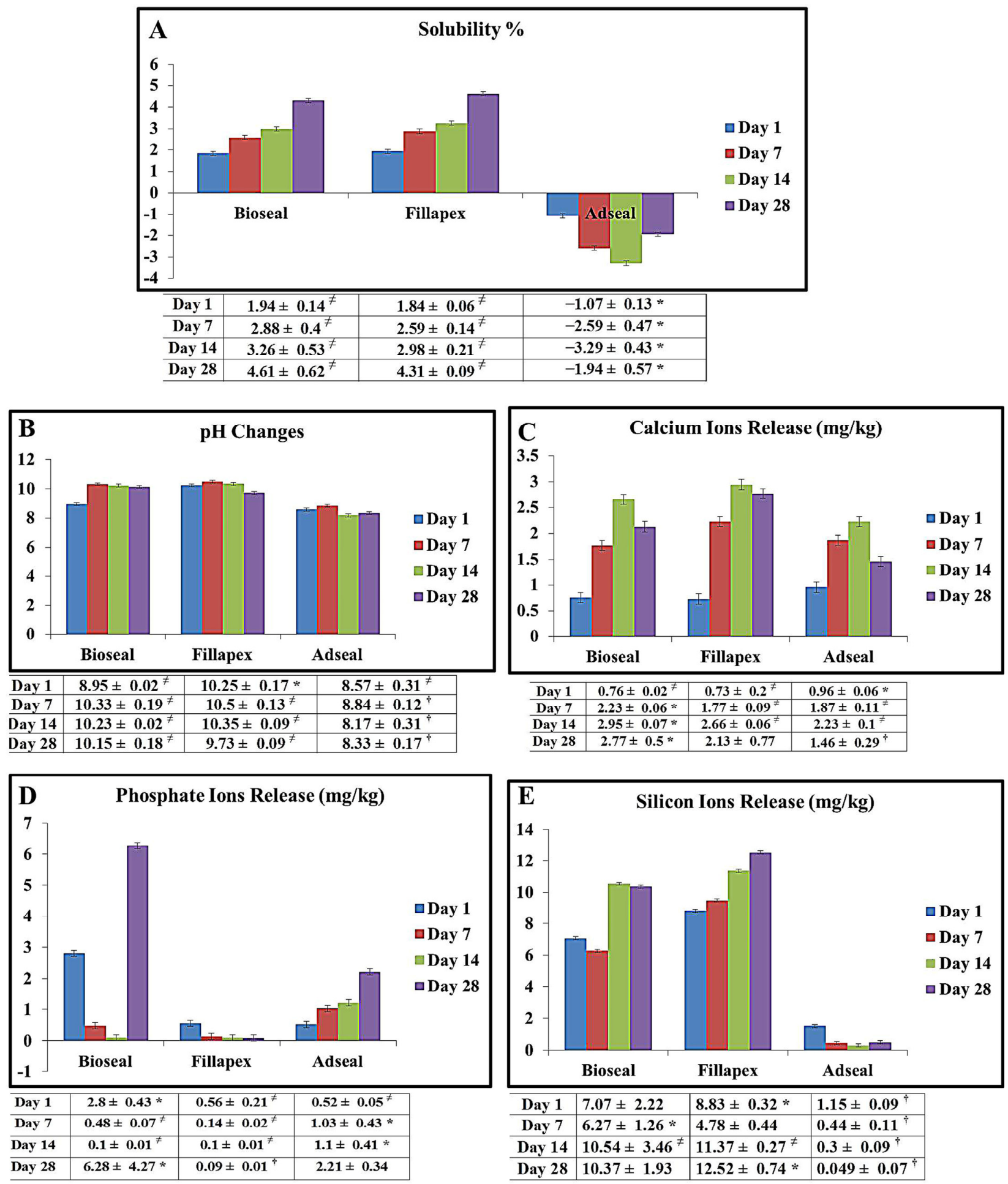

Figure 2. Histograms representing the mean values of solubility $\%(\mathbf{A}), \mathrm{pH}$ changes (B), $\mathrm{Ca}^{2+}$ ion release $(\mathbf{C}), \mathrm{PO}_{4}{ }^{3-}$ ion release (D), and $\mathrm{Si}^{4+}$ ion release (E) of the root canal sealers over the immersion times of the experiment. ${ }^{*}$ indicates the highest significant value (at $p<0.001) .{ }^{\dagger}$ indicates the lowest significant value $($ at $p<0.001) . \neq$ indicates no significant difference between sealers of the same symbol $(p>0.05)$. 


\section{3. $p H$ Changes}

As shown in Figure 2B, the MTA-Fillapex incubation solution underwent a rapid $\mathrm{pH}$ increase after the first day, reaching 10.25 . The $\mathrm{pH}$ of the solution decreased to 9.73 after 28 days. The MTA-Bioseal solution did not show a similar high $\mathrm{pH}$ value after one day. However, it gradually increased over time, and by day 28 it had plateaued at a significantly higher $\mathrm{pH}$ than the MTA-Fillapex solution $(p<0.001)$. At each observation point, the solutions of the two MTA-based sealers had higher $\mathrm{pH}$ levels than that of Adseal (Figure 2B).

\subsection{Calcium, Phosphate, and Silicon Ions Released}

After the first day, Adseal had released significantly more $\mathrm{Ca}^{2+}$ ions than either of the MTA-based sealers $(p<0.001)$; however, MTA-Fillapex released significantly more $\mathrm{Ca}^{2+}$ than the others throughout the remaining immersion period $(p<0.001)$. At the end of the experiment, Adseal was found to release the least amount of $\mathrm{Ca}^{2+}(p<0.001)$ (Figure 2C).

The three sealers exhibited variable leaching patterns for $\mathrm{PO}_{4}{ }^{3-}$ (Figure 2D). MTABioseal released the largest amount of $\mathrm{PO}_{4}{ }^{3-}$ after the first day $(p<0.001)$. It then showed a sharp decline in the registered quantity, followed by a sharp increase to become the highest $\mathrm{PO}_{4}{ }^{3-}$ releasing sealer by the end of the observation period $(p<0.001)$. MTAFillapex and Adseal demonstrated opposite patterns. The amount of $\mathrm{PO}_{4}{ }^{3-}$ released by MTA-Fillapex consistently decreased with time, while the amount released by Adseal consistently increased (Figure 2D).

Figure 2E shows that MTA-Fillapex consistently released the largest amount of $\mathrm{Si}^{4+}$ throughout the observation period, followed by MTA-Bioseal, while Adseal consistently released the least amount $(p<0.001)$.

\subsection{SEM/EDX Analysis}

\subsubsection{Characterization of Sealers before Solubility Test}

The MTA-Bioseal exhibited a homogeneous surface structure with similarly sized globular particles (Figure 3A). The surface also exhibited grayish areas between the particles and scattered bright dots of radio-opacifiers.

The surface of MTA-Fillapex showed a homogeneous layer of differently shaped particles that were mainly globular (belite) with a few scattered, irregularly shaped particles (alite) and elongated, irregular, bright particles of bismuth oxide in between (Figure 3B).

The Adseal surface showed a uniform structure of irregular small particles and bright radio-opacifier particles. The surfaces of the three materials contained microporosities. The largest number of microporosities was recorded for Adseal (large number of small microporosities, ranging from 10 to $54 \mu \mathrm{m}^{2}$ in size), followed by MTA-Bioseal (few microporosities, with large irregular spaces; porosities ranged from 54 to $83 \mu \mathrm{m}^{2}$ in size). The fewest microporosities were seen on the surface of MTA-Fillapex (few porosities, with small sizes ranging from 2.7 to $11.4 \mu^{2}$ ) (Figure $3 \mathrm{~A}-\mathrm{C}$ ).

The EDX analysis revealed that the three sealers were composed of carbon (C), oxygen $(\mathrm{O})$, silicon $(\mathrm{Si})$, phosphate $(\mathrm{P})$, and calcium $(\mathrm{Ca})$ at different concentrations (Figure 3D-F). Ca was significantly higher in MTA-Bioseal $(p<0.001)$, whereas Si was significantly higher in MTA-Fillapex $(p=0.003)$. Both of the MTA-based sealers contained aluminum (Al), whereas sulfur (S) was only detected in MTA-Bioseal. MTA-Fillapex and Adseal contained the same radio-opacifier (bismuth (Bi)), while MTA-Bioseal contained strontium ( $\mathrm{Sr}$ ) and titanium (Ti). 


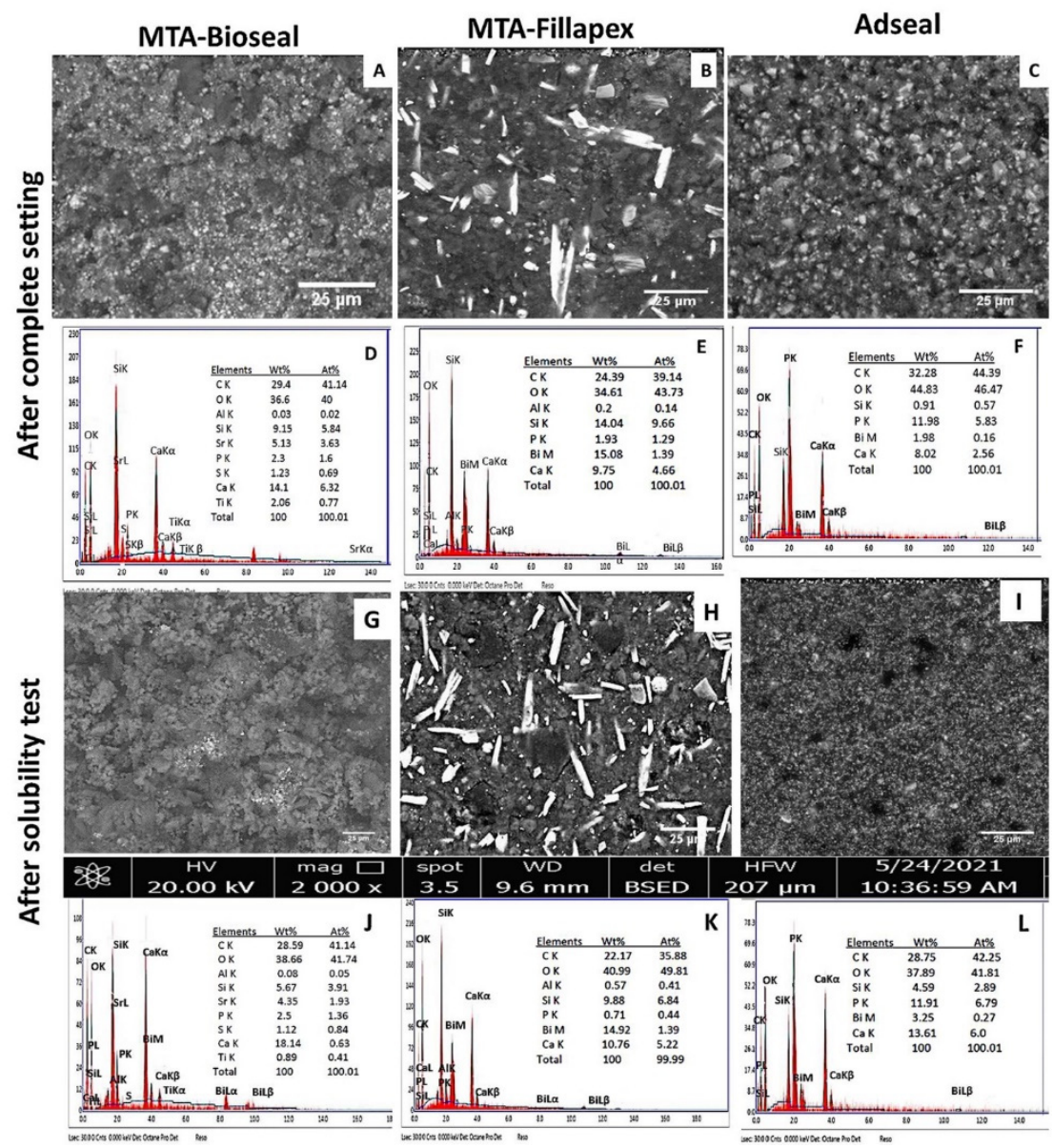

Figure 3. SEM examination of surface structure (A-C) and EDX analysis (D-F) of MTA-Bioseal, MTAFillapex, and Adseal before immersion in deionized water. SEM examination of surface structure (G-I) and EDX analysis (J-L) of MTA-Bioseal, MTA-Fillapex, and Adseal after immersion in deionized water for 28 days. Magnification $\times 2000$.

\subsubsection{Characterization of Sealers after Solubility Test}

After being stored in deionized water for 28 days, the MTA-Bioseal surface showed a collapse of the micropores (Figure 3G), whereas the pores of MTA-Fillapex and Adseal became fewer in number and larger in size, ranging from 180 to $455 \mu^{2}$ and from 8.4 to $18.9 \mu \mathrm{m}^{2}$, respectively (Figure $3 \mathrm{H}, \mathrm{I}$ ).

EDX analysis revealed a decrease in the amount of Si on the surface of the two MTAbased sealers and an increase in Ca in all three sealers (Figure 3J-L).

\subsection{Flow/Film Thickness}

MTA-Fillapex registered the lowest mean flowability value $(19.5 \pm 0.35 \mathrm{~mm})$, which was significantly lower than that of MTA-Bioseal $(22.1 \pm 0.42 \mathrm{~mm})$ and Adseal $(21.0 \pm 0.61 \mathrm{~mm})$ $(p<0.001)$. The two MTA-based sealers exhibited a similar thickness $(50 \mu \mathrm{m})$, while Adseal showed a significantly greater thickness $(130 \pm 30 \mu \mathrm{m})(p<0.001)$.

\section{Discussion}

The current study evaluated several physicochemical properties of MTA-Fillapex, MTA-Bioseal, and Adseal, as well as the effect of solubility on their surface morphology and composition. To the best of our knowledge, no previous studies have evaluated MTA- Bioseal. Our results showed that the three sealers differed in composition, degree of solubility, $\mathrm{pH}$ change in the surrounding medium, and type and concentration of released elements. The sealers also showed changes in their surface after being immersed 
in deionized water for 28 days. They also differed in their film thickness and flowability. Hence, the null hypothesis was rejected.

According to manufacturer information, MTA-Bioseal and MTA-Fillapex are composed of salicylic resin, $40 \%$ MTA $\left(C_{3} S, C_{2} S\right.$, tricalcium aluminate, and calcium oxide), and radio-opacifiers $[3,8]$. The current study was the first to evaluate the properties and composition of MTA-Bioseal. The chemical composition of MTA-Fillapex has been extensively investigated [25-27]. The current EDX analysis detected $\mathrm{C}, \mathrm{O}, \mathrm{Al}, \mathrm{Si}, \mathrm{P}$, and Ca in both of the MTA-based sealers (Figure 3D,E). This finding was in line with several previous studies $[25,26,28,29]$. To reduce cytotoxicity, the newer MTA-Bioseal included a lower Al percentage of $\approx 0.05 \mathrm{wt} \%$ instead of $\approx 0.2 \mathrm{wt} \%$ in MTA-Fillapex [30]; it also contained $\mathrm{Sr}$ and Ti as radio-opacifiers instead of Bi, which is in MTA-Fillapex [31]. Cell viability is significantly decreased in the presence of $\mathrm{Bi}$, while the opposite was true for $\mathrm{Sr}$ [31]. The addition of Ti to the sealer has been previously reported and is owing to its effective antifungal properties [32]. Phosphorus is added to enhance the bioactivity and apatite formation of MTA-based sealers [33]. The FTIR spectra of MTA-Bioseal and Fillapex showed similar compositions with variable intensity bands. Their spectra showed bands for $\mathrm{Ca}(\mathrm{OH})_{2}$, methyl $(\mathrm{C}-\mathrm{H})$, and carbonyl $(\mathrm{C}=\mathrm{O})$ groups of salicylate resin and carbonate $\left(\mathrm{CO}_{3}\right)$, sulfate $\left(\mathrm{SO}_{4}\right)$, and $\mathrm{SiO}_{4}$ groups of calcium silicate hydrate $(\mathrm{CSH})$. There were small bands for polymerized silicate (CxS), di-calcium silicate $\left(\mathrm{C}_{2} \mathrm{~S}\right)$, and / or tri-calcium silicate $\left(\mathrm{C}_{3} \mathrm{~S}\right)$. The phosphate $\left(\mathrm{v}_{3}\right.$ and $\left.\mathrm{v}_{4} \mathrm{PO}_{4}{ }^{3-}\right)$ bands were more prominent in the spectra of MTA-Bioseal, indicating its prominent bioactivity.

Sealer solubility is unfavorable because when a sealer disintegrates in the surrounding tissues it can lead to inflammatory and cytotoxic reactions [29]. According to international standards (ISO 6876 and ANSI/ADA Specification No. 57), the solubility of root canal sealers should not exceed 3\% mass fraction when stored in water [6,34-36].

The results showed that the MTA-based sealers had similar high solubility that gradually increased over time and exceeded $>4 \%$ mass fraction by the end of the observation period (Figure 2A). Several studies have reported a high solubility for MTA-Fillapex [7,36-40] that exceeds the acceptable limit [36]. However, other studies have detected lower weight loss values ranging from $0.25 \%$ after 28 days [41] to $4.65 \%$ after 6 months [6]. Such variability could be attributed to sealer shrinkage after immersion in water [42], excessive disintegrated elements leaching into the aqueous medium [43], or instability of the sealer matrix upon hydration with more soluble incorporated additives [36]. The current study found an increase in the leachable amount of $\mathrm{Si}^{4+}$ (Figure 2E) and a reduction in $\mathrm{Si} \mathrm{wt} \%$ on the surface of both MTA-based sealers after 28 days of water immersion (Figure 3J,K), which supports these suggestions [43]. In addition, the presence of hydrophilic particles on the surface of the MTA-based sealer allows more water molecules to encounter the sealer, thereby increasing its solubility [34].

Adseal is an epoxy resin-based sealer containing calcium phosphate, amines, and bismuth subcarbonate [44,45]. It was chosen as a control because of its resistance to solubility [29,46,47]; this resistance could explain why Adseal displayed a negative solubility \% (Figure 2A). Adseal showed reduced leaching of $\mathrm{Ca}^{2+}$ and $\mathrm{Si}^{4+}$ compared to the MTA-based sealers, which might be attributable to elements being more thoroughly incorporated within the matrix during material polymerization. Adseal gained weight, which could be attributed to the susceptibility of the resin-based sealer to water sorption and a high expansion potential during and after polymerization [29,48]. Increased solubility was observed for Adseal by day 28. This can be attributed to the disintegration and breakdown of unreacted polymerized particles [49].

Changes in $\mathrm{pH}$ have been related to the degree of solubility and the amount of $\mathrm{Ca}^{2+}$ released $[6,38,46]$. The $\mathrm{pH}$ changes were attributed to the formation of calcium hydroxide during the hydration reaction followed by its dissociation into $\mathrm{OH}^{-}$and $\mathrm{Ca}^{2+}[46]$. This was confirmed by the significantly higher $\mathrm{Ca}^{2+}$ release for the two MTA-based sealers, with a maximum value at 21 days (Figure 2C). In the current study, both MTA-based sealers showed the highest mean value on day 7 . The same $\mathrm{pH}$ value for the MTA-Fillapex solution 
was previously recorded in several studies $[6,25,38,39,42]$, while a lower $\mathrm{pH}$ value (7.7-9.39) was recorded by others [27,50]. This suggests that $\mathrm{pH}$ changes are related to time [38]. Among the experimental periods, the MTA-Bioseal solution showed a higher $\mathrm{pH}$ value (Figure 2B) than that stated by the manufacturer $(\mathrm{pH}=9)$ [8]

The high alkalinity of the MTA-based sealer solutions may be attributed to the pozzolanic reaction and the formation of $\mathrm{Ca}(\mathrm{OH})_{2}$ during the hydration reaction. $\mathrm{Ca}(\mathrm{OH})_{2}$ dissociates into $\mathrm{OH}^{-}$and $\mathrm{Ca}^{2+}$, which promote antibacterial ability and osteogenic potential, respectively [6,51-53]. However, the prolonged alkalinity of the MTA-based sealer solutions might be considered as a source of cytotoxicity, leading to protein destruction and enzymatic cell membrane denaturation [54]. This adverse effect could be of clinical concern, as our results showed an increase in Ca wt $\%$ on the sealers' surfaces (Figure 3J,K). Such accumulation might lead to cytotoxic events. A higher calcium content released by MTA-Fillapex compared with epoxy resin has been previously reported [40,50]. Siboni et al. reported that the maximum calcium content released by MTA-Fillapex was detected within the first 3 days, while epoxy resin (AHplus) did not exhibit calcium release at all [27]. The Adseal solution was weakly alkaline (Figure $2 \mathrm{~B}$ ), in contrast to the nearly neutral $\mathrm{pH}$ $(\approx 7.5)$ [29] or acidic $\mathrm{pH}(\leq 6.5)[55]$ previously recorded. The lower $\mathrm{pH}$ changes induced by Adseal might be related to its lower solubility and reduced $\mathrm{Ca}^{2+}$ release.

The prolonged release of $\mathrm{Ca}^{2+}, \mathrm{PO}_{4}{ }^{3-}$, and $\mathrm{Si}^{4+}$ results in degradation of the sealer's surface. SEM/EDX analysis revealed a decrease in the Si wt\% (Figure 3D,E,J,K), with large micropores detected in both of the MTA-based sealers. MTA-Fillapex released a significant amount of $\mathrm{Ca}^{2+}$ and $\mathrm{Si}^{4+}$. This has been previously reported [52]. MTA-Bioseal demonstrated the greatest $\mathrm{PO}_{4}{ }^{3-}$ release (Figure 2C-E), which might be due to its higher $\mathrm{P}$ content compared with MTA-Fillapex, as detected by EDX. The marked increase in $\mathrm{PO}_{4}{ }^{3-}$ by the end of the observation period might have been due to its lack of attachment within the set sealer. This amount of $\mathrm{PO}_{4}{ }^{3-}$ release might enhance its bioactivity [33]. Conversely, Adseal showed greater $\mathrm{PO}_{4}{ }^{3-}$ release, which increased over time. This finding might be due to its greater $\mathrm{P}$ content, as detected by EDX.

The FTIR analysis identified $\mathrm{PO}_{4}{ }^{3-}$ in the spectra of MTA-Bioseal and Adseal at 1086 and $1031 \mathrm{~cm}^{-1}$, respectively $[16,20,22]$. The largest $\mathrm{PO}_{4}{ }^{3-}$ release was exhibited by MTABioseal, followed by Adseal (Figure 2D). It appeared that $\mathrm{PO}_{4}{ }^{3-}$ was not well incorporated into the CSH structure of MTA-Bioseal; hence, it was easily released into the aqueous medium. Adseal is mainly composed of calcium phosphate [44]; thus, after polymerization, $\mathrm{PO}_{4}{ }^{3-}$ became incorporated within the sealer and was slowly released. The presence of $\mathrm{PO}_{4}{ }^{3-}$ within the sealer seems to enhance its bioactivity. This finding corroborated previous results [56].

The surfaces of the three materials contained microporosities, with the largest sizes in MTA-Fillapex. MTA-Fillapex exhibits a homogeneous surface with various sizes of porosities [38]. This may be related to the setting characteristics and the formation of a polymerized silicate phase [37]. Previous reports have shown that MTA-Fillapex is unable to set, even after 1 month [29]. Here, the FTIR spectra confirmed the presence of unhydrated calcium silicate $\left(\mathrm{C}_{3} \mathrm{~S}\right.$ and $\left.\mathrm{C}_{2} \mathrm{~S}\right)$ particles and little polymerized calcium silicate (CxS), with a low content of polymerized calcium silicate (CSH) [29]. Furthermore, there was low intensity of the $\mathrm{SiO}_{4}$ band at $900-800 \mathrm{~cm}^{-1}$ [19]. The presence of unhydrated silicate phase is responsible for the excessive $\mathrm{Si}^{4+}$ release and for the large micropores on the MTA-Fillapex surface. It is assumed that these micropores can hold water from the surrounding environment, allowing bacterial colonization [57]. Whether this would impact the long-term outcome of endodontic treatment warrants further clinical investigation.

Although improved flowability facilitates a sealer's penetration into canal irregularities, excessive flow has been considered as a risk factor for extrusion and can potentially provoke inflammatory and cytotoxic reactions [41]. According to the ISO standard, the three tested sealers met the adequate flow specification (>17 mm) [10], with MTA-Bioseal registering the highest flowability, followed by Adseal and MTA-Fillapex. Previous studies have reported a wide range of MTA-Fillapex flowabilities (22-34 mm) $[29,36,41,58]$. Such 
high flowability could be due to a prolonged setting time [25,37] or a high resin/MTA ratio when used from freshly opened tubes [41].

Regarding film thickness, both MTA-Bioseal and Fillapex complied with the ISO standard $(50 \mu \mathrm{m})$ [10], but Adseal had a high value $(130 \pm 30 \mu \mathrm{m})$. Previous studies have reported thick films for MTA-Fillapex $(75 \pm 12 \mu \mathrm{m})$ [36,42] and Adseal $(0.083 \mathrm{~mm})$ [44]. The flowability and film thickness of sealers may be influenced by their composition, small particle size, and setting characteristics [58]. The greater film thickness of Adseal can be attributed to its expansion after polymerization $[29,48]$.

\section{Conclusions}

The three sealers differed in their composition, degree of solubility, induced $\mathrm{pH}$ changes in the surrounding medium, type and concentration of released elements, surface changes upon immersion in deionized water over 28 days, film thickness, and flowability. The two MTA-based sealers exhibited high solution alkalinity and released a considerable amount of $\mathrm{Ca}^{2+}$, which is conducive to osteogenic behavior. The greater solubility and $\mathrm{Si}^{4+}$ release exhibited by MTA-Fillapex might have led to the development of large micropores on its surface, which would compromise the apical sealing of the root canal system. This could be a clinical concern jeopardizing the long-term outcome of root canal treatment. Hence, clinicians should maximize efforts to limit contact of MTA-Fillapex with the surrounding periapical tissues. Further investigations are needed to evaluate the setting characteristics of MTA-based root canal sealers.

Despite the meticulous approach adopted in this study, the lack of moist conditions provided by dentinal tubule fluids, which aids in the setting reaction of MTA-based sealers, limits the extrapolation of our results to the clinical setting.

Author Contributions: Conceptualization, S.A.Z.; data curation, S.A.Z.; formal analysis, S.A.Z., H.Y.E., A.A.M.S. and O.S.A.; funding acquisition, H.Y.E., A.A.M.S. and O.S.A.; investigation, S.A.Z. and H.Y.E.; methodology, S.A.Z. and H.Y.E.; resources, S.A.Z., H.Y.E., A.A.M.S. and O.S.A.; supervision, S.A.Z.; validation, S.A.Z.; writing —original draft, S.A.Z.; writing-review and editing, H.Y.E., A.A.M.S. and O.S.A. All authors have read and agreed to the published version of the manuscript.

Funding: This research received no external funding.

Institutional Review Board Statement: Not applicable.

Informed Consent Statement: Not applicable.

Data Availability Statement: Data available in a publicly accessible repository.

Conflicts of Interest: The authors declare no conflict of interest.

\section{References}

1. Ørstavik, D. Materials used for root canal obturation: Technical, biological and clinical testing. Endod. Top. 2005, 12, 25-38. [CrossRef]

2. Parirokh, M.; Torabinejad, M. Mineral trioxide aggregate: A comprehensive literature review-part I: Chemical, physical, and antibacterial properties. J. Endod. 2010, 36, 16-27. [CrossRef]

3. Angulus Science and Technology. MTA-Fillapex Endodontic Sealer, Scientific Profile. 2011. Available online: http://www. angelusdental.com/img/arquivos/mta_fillapex_technical_profile_download.pdf (accessed on 22 August 2021).

4. Johnson, W.T.; Kulild, J.C.; Tay, F. Obturation of the cleaned and shaped root canal system. In Pathways of the Pulp, 11th ed.; Elsevier: Amsterdam, The Netherlands, 2016; pp. 280-322.

5. Abu Zeid, S.T.H.; Saleh, A.A.Y.M. Solubility, pH Changes and Releasing Elements of Different Bioceramic and Mineral Trioxide Aggregate Root Canal Sealers Comparative Study. Trauma Treat 2015, 4, 1-4.

6. Urban, K.; Neuhaus, J.; Donnermeyer, D.; Schäfer, E.; Dammaschke, T. Solubility and pH value of 3 different root canal sealers: A long-term investigation. J. Endod. 2018, 44, 1736-1740. [CrossRef] [PubMed]

7. Da Silva, E.J.N.L.; Accorsi-Mendonça, T.; Pedrosa, A.C.; Granjeiro, J.M.; Zaia, A.A. Long-term cytotoxicity, pH and dissolution rate of AH Plus and MTA Fillapex. Brazil. Dent. J. 2016, 27, 419-423. [CrossRef]

8. ITENA Clinical Product. MTA-Bioseal, White Paper-Dental Sky. 2018. Available online: WP_MTABIOSEAL.pdf(dentex.ro) (accessed on 20 August 2021). 
9. American National Standards Institute. American Dental Association Specification no. 57 for endodontic filling materials. J. Am. Dent. Assoc. 2000, 108, 88.

10. International Standardization Organization. ISO 6876: Dental Root Canal Sealing Materials; International Organization for Standardization: Geneva, Swizerland, 2012.

11. McMichen, F.; Pearson, G.; Rahbaran, S.; Gulabivala, K. A comparative study of selected physical properties of five root-canal sealers. Int. Endod. J. 2003, 36, 629-635. [CrossRef]

12. Kim, J.; Vipulanandan, C. Effect of pH, sulfate and sodium on the EDTA titration of calcium. Cem. Concr. Res. 2003, 33, 621-627. [CrossRef]

13. Mussa, S.B.; Elferjani, H.S.; Haroun, F.A.; Abdelnabi, F.F. Determination of available nitrate, phosphate and sulfate in soil samples. Int. J. PharmTech Res. 2009, 1, 598-604.

14. Olsen, S.R.; Sommers, L.E. Phosphorus. In Methods of Soil Analysis: Part 2 Chemical and Microbiological Properties, 2nd ed.; American Society of Agronomy: Madison, WI, USA, 1983; pp. 403-430.

15. de Miranda Candeiro, G.T.; Correia, F.C.; Duarte, M.A.H.; Ribeiro-Siqueira, D.C.; Gavini, G. Evaluation of radiopacity, pH, release of calcium ions, and flow of a bioceramic root canal sealer. J. Endod. 2012, 38, 842-845. [CrossRef]

16. Ahmadi, S.M.; Behnamghader, A.; Sharifipoor, S.; Farsadzadeh, B. Effect of nano flourhydroxyapatite (nFHA) addition on the acellular bioactivity of MTA cement: An in vitro assessment. In Proceedings of the 4 th International Conference on Nanostructures (ICNS4), Kish Island, Iran, 12-14 March 2012; pp. 12-14.

17. Gandolfi, M.G.; Taddei, P.; Tinti, A.; Prati, C. Apatite-forming ability (bioactivity) of ProRoot MTA. Int. Endod. J. 2010, 43, 917-929. [CrossRef]

18. Okamura, T.; Chen, L.; Tsumano, N.; Ikeda, C.; Komasa, S.; Tominaga, K.; Hashimoto, Y. Biocompatibility of a High-Plasticity, Calcium Silicate-Based, Ready-to-Use Material. Materials 2020, 13, 4770. [CrossRef]

19. Ylmén, R.; Jäglid, U.; Steenari, B.-M.; Panas, I. Early hydration and setting of Portland cement monitored by IR, SEM and Vicat techniques. Cem. Concr. Res. 2009, 39, 433-439. [CrossRef]

20. Boskey, A.; Camacho, N.P. FT-IR imaging of native and tissue-engineered bone and cartilage. Biomaterials 2007, 28, 2465-2478. [CrossRef]

21. Delgado, A.H.; Young, A.M. Modelling ATR-FTIR Spectra of Dental Bonding Systems to Investigate Composition and Polymerisation Kinetics. Materials 2021, 14, 760. [CrossRef]

22. Jayasree, R.; Kumar, T.S.; Kavya, K.P.S.; Nankar, P.; Mukesh, D. Self setting bone cement formulations based on egg shell derived tetracalcium phosphate bioceramics. Bioceram. Dev. Appl. 2015, 5, 2.

23. Radwan, M.; Nagi, S.M.; Abd El-Hamid, H. Physico-mechanical characteristics of tri-calcium silicate pastes as dentin substitute and interface analysis in class II cavities: Effect of $\mathrm{CaCl}_{2}$ and SBF solutions. Heliyon 2019, 5, e01975. [CrossRef]

24. Trezza, M.A. Hydration study of ordinary portland cement in the presence of zinc ions. Mater. Res. 2007, 10, 331-334. [CrossRef]

25. Benezra, M.K.; Wismayer, P.S.; Camilleri, J. Influence of environment on testing of hydraulic sealers. Sci. Rep. 2017, 7, 1-11.

26. Sampaio, F.C.; Alencar, A.H.G.D.; Guedes, O.A.; Veloso, H.H.P.; Santos, T.O.D.; Estrela, C. Chemical elements characterization of root canal sealers using scanning electron microscopy and energy dispersive X-ray analysis. Oral Health Dent. Manag. 2014, 13, 27-34. [PubMed]

27. Siboni, F.; Taddei, P.; Zamparini, F.; Prati, C.; Gandolfi, M.G. Properties of BioRoot RCS, a tricalcium silicate endodontic sealer modified with povidone and polycarboxylate. Int. Endod. J. 2017, 50, e120-e136. [CrossRef] [PubMed]

28. Reszka, P.; Nowicka, A.; Lipski, M.; Dura, W.; Droździk, A.; Woźniak, K. A comparative chemical study of calcium silicatecontaining and epoxy resin-based root canal sealers. BioMed Res. Int. 2016, 2016, 9808432. [CrossRef]

29. Lee, J.K.; Kwak, S.W.; Ha, J.-H.; Lee, W.; Kim, H.-C. Physicochemical properties of epoxy resin-based and bioceramic-based root canal sealers. Bioinorg. Chem. Appl. 2017, 2017, 2582849. [CrossRef]

30. Drukteinis, S.; Camilleri, J. Bioceramic Materials in Clinical Endodontics; Springer: Berlin/Heidelberg, Germany, 2021.

31. Antonijević, D.; Despotović, A.; Biočanin, V.; Milošević, M.; Trišić, D.; Lazović, V.; Zogović, N.; Milašin, J.; Ilić, D. Influence of the addition of different radiopacifiers and bioactive nano-hydroxyapatite on physicochemical and biological properties of calcium silicate based endodontic ceramic. Ceram Int. 2021, 47, 28913-28923. [CrossRef]

32. Raura, N.; Garg, A.; Arora, A.; Roma, M. Nanoparticle technology and its implications in endodontics: A review. Biomater. Res. 2020, 24, 1-8. [CrossRef] [PubMed]

33. Al-Sanabani, J.S.; Madfa, A.A.; Al-Sanabani, F.A. Application of calcium phosphate materials in dentistry. Int. J. Biomater. 2013, 2013, 876132. [CrossRef]

34. Poggio, C.; Dagna, A.; Ceci, M.; Meravini, M.-V.; Colombo, M.; Pietrocola, G. Solubility and pH of bioceramic root canal sealers: A comparative study. J. Clin. Exp. Dent. 2017, 9, e1189. [CrossRef] [PubMed]

35. Borges, Á.H.; Pedro, F.L.; Miranda, C.E.; Semenoff-Segundo, A.; Pécora, J.D.; Cruz Filho, A.M. Comparative study of physicochemical properties of MTA-based and Portland cements. Acta Odontol. Latinoam. 2010, 23, 175-181. [PubMed]

36. Viapiana, R.; Flumignan, D.; Guerreiro-Tanomaru, J.; Camilleri, J.; Tanomaru-Filho, M. Physicochemical and mechanical properties of zirconium oxide and niobium oxide modified P ortland cement-based experimental endodontic sealers. Int. Endod. J. 2014, 47, 437-448. [CrossRef] [PubMed] 
37. Amoroso-Silva, P.A.; Guimarães, B.M.; Marciano, M.A.; Duarte, M.A.H.; Cavenago, B.C.; Ordinola-Zapata, R.; De Almeida, M.M.; De Moraes, I.G. Microscopic analysis of the quality of obturation and physical properties of MTA F illapex. Microsc. Res. Tech. 2014, 77, 1031-1036. [CrossRef]

38. Borges, Á.H.; Dorileo, O.; Gonçales, M.C.; Villa, R.D.; Borba, A.M.; Semenoff, T.A.D.V.; Guedes, O.A.; Estrela, C.R.A.; Bandéca, M.C. Physicochemical properties and surfaces morphologies evaluation of MTA FillApex and AH plus. Sci. World J. 2014, 2014, 589732. [CrossRef]

39. Faria-Júnior, N.; Tanomaru-Filho, M.; Berbert, F.L.C.V.; Guerreiro-Tanomaru, J. Antibiofilm activity, pH and solubility of endodontic sealers. Int. Endod. J. 2013, 46, 755-762. [CrossRef]

40. Jafari, F.; Jafari, S. Composition and physicochemical properties of calcium silicate based sealers: A review article. J. Clin. Exp. Dent. 2017, 9, e1249. [CrossRef] [PubMed]

41. Vitti, R.P.; Prati, C.; Silva, E.J.N.L.; Sinhoreti, M.A.C.; Zanchi, C.H.; Silva, M.G.D.S.E.; Guedes, O.A.; Estrela, C.R.A.; Bandéca, M.C. Physical properties of MTA Fillapex sealer. J. Endod. 2013, 39, 915-918. [CrossRef] [PubMed]

42. Zhou, H.-M.; Shen, Y.; Zheng, W.; Li, L.; Zheng, Y.-F. Haapasalo, M. Physical properties of 5 root canal sealers. J. Endod. 2013, 39, 1281-1286. [CrossRef] [PubMed]

43. Tagger, M.; Tagger, E.; Kfir, A. Release of calcium and hydroxyl ions from set endodontic sealers containing calcium hydroxide. J. Endod. 1988, 14, 588-591. [CrossRef]

44. Cardona Hidalgo, J.C.; González Carreño, J.M.; Avendaño Rueda, J.C. Physicochemical properties of two epoxy resin-based sealants: Topseal ${ }^{\circledR}$ and AdSeal ${ }^{\mathrm{TM}}$. A comparative study. Rev. Fac. Odontol. Univ. Antioq. 2019, 31, 68-76.

45. Marciano, M.A.; Guimarães, B.M.; Ordinola-Zapata, R.; Bramante, C.M.; Cavenago, B.C.; Garcia, R.B.; Bernardineli, N.; Andrade, F.; Moraes, I.G.; Duarte, M.A.H. Physical properties and interfacial adaptation of three epoxy resin-based sealers. J. Endod. 2011, 37, 1417-1421. [CrossRef]

46. Huang, T.-H.; Kao, C.-T. pH measurement of root canal sealers. J. Endod. 1998, 24, 236-238. [CrossRef]

47. Schäfer, E.; Zandbiglari, T. Solubility of root canal sealers in water and artificial saliva. Int. Endod. J. 2003, 36, 660-669. [CrossRef] [PubMed]

48. Carvalho-Júnior, J.R.; Guimarães, L.F.L.; Correr-Sobrinho, L.; Pécora, J.D.; Sousa-Neto, M.D. Evaluation of solubility, disintegration, and dimensional alterations of a glass ionomer root canal sealer. Brazil. Dent. J. 2003, 14, 114-118. [CrossRef]

49. Azadi, N.; Fallahdoost, A.; Mehrvarzfar, P.; Rakhshan, H.; Rakhshan, V. A four-week solubility assessment of AH-26 and four new root canal sealers. Dent. Res. J. 2012, 9, 31.

50. Kuga, M.C.; Faria, G.; Weckwerth, P.H.; Duarte, M.A.H.; Campos, E.A.D.; Só, M.V.R.; Voila, K.S. Evaluation of the pH, calcium release and antibacterial activity of MTA Fillapex. Rev. Odontol. UNESP 2013, 42, 330-335. [CrossRef]

51. Desai, S.; Chandler, N. Calcium hydroxide-based root canal sealers: A review. J. Endod. 2009, 35, 475-480. [CrossRef]

52. McHugh, C.P.; Zhang, P.; Michalek, S.; Eleazer, P.D. pH required to kill Enterococcus faecalis in vitro. J. Endod. 2004, 30, 218-219. [CrossRef] [PubMed]

53. Edrees, H.Y.; Abu Zeid, S.T.; Atta, H.M.; AlQriqri, M.A. Induction of osteogenic differentiation of mesenchymal stem cells by bioceramic root repair material. Materials 2019, 12, 2311. [CrossRef]

54. Yoshino, P.; Nishiyama, C.K.; Modena, K.C.D.S.; Santos, C.F.; Sipert, C.R. In vitro cytotoxicity of white MTA, MTA Fillapex ${ }^{\circledR}$ and Portland cement on human periodontal ligament fibroblasts. Brazil. Dent. J. 2013, 24, 111-116. [CrossRef] [PubMed]

55. Song, Y.-S.; Choi, Y.; Lim, M.-J.; Yu, M.-K.; Hong, C.-U.; Lee, K.-W.; Min, K.-S. In vitro evaluation of a newly produced resin-based endodontic sealer. Restor. Dent. Endod. 2016, 41, 189. [CrossRef] [PubMed]

56. Xuereb, M.; Vella, P.; Damidot, D.; Sammut, C.V.; Camilleri, J. In situ assessment of the setting of tricalcium silicate-based sealers using a dentin pressure model. J. Endod. 2015, 41, 111-124. [CrossRef] [PubMed]

57. Gandolfi, M.; Siboni, F.; Prati, C. Properties of a novel polysiloxane-guttapercha calcium silicate-bioglass-containing root canal sealer. Dent. Mater. 2016, 32, e113-e126. [CrossRef]

58. Silva, E.J.; Rosa, T.P.; Herrera, D.R.; Jacinto, R.C.; Gomes, B.P.; Zaia, A.A. Evaluation of cytotoxicity and physicochemical properties of calcium silicate-based endodontic sealer MTA Fillapex. J. Endod. 2013, 39, 274-277. [CrossRef] [PubMed] 